\title{
European apple canker: morphophysiological variability and pathogenicity in isolates of Neonectria ditissima in southern Brazil
}

\author{
Jonatas da Silva Campos ${ }^{1}$ Amauri Bogo ${ }^{1^{*}}$ Rosa Maria Valdebenito Sanhueza $^{2}$ Ricardo Trezzi \\ Casa $^{1}$ Fabio Nascimento da Silva ${ }^{1}$ Isabel Cristina da Cunha ${ }^{3}$ Paulo Roberto Kuhnem Júnior ${ }^{4}$
}

${ }^{1}$ Programa de Pós-graduação em Produção Vegetal, Centro de Ciências Agroveterinárias, Universidade do Estado de Santa Catarina (UDESC), Lages, SC, Brasil. E-mail: amauri.bogo@udesc.br. "Corresponding author.

${ }^{2}$ Proterra Consultoria Agronômica, Vacaria, RS, Brasil.

${ }^{3}$ Centro de Educação a Distância, Universidade do Estado de Santa Catarina (UDESC), Florianópolis, SC, Brasil.

${ }^{4}$ OR Sementes, Passo Fundo, RS, Brasil.

\begin{abstract}
European apple canker (EC) is caused by Neonectria ditissima, a pathogen officially registered as a quarantine pest in 2012. Thirtyfive isolates of $N$. ditissima of different geographical regions of southern Brazil from apple branches showing symptoms of EC were identified by the specific pair primers Ch1 and Ch2 and analyzed concerning the virulence on Gala apple cultivar and morphophysiological characteristics. The disease symptoms were characterized and the isolates compared based on average mycelium growth (AMG), mycelium growth index (MGI), colony color, conidia type, dimensions and growth on potato dextrose agar (PDA), malt agar (AM), and synthetic SNAY (SN) culture media. Nineteen isolates showed the greatest AMG on PDA, forming three growth groups of 35.56 (GI), 52.71 (GII), and 62.67mm (GIII). Seven isolates showed MGI greater than 4.0mm diameter on PDA compared with that on AM and SN. The highest conidia production was on SN, and the predominant colony color in all media was white to beige with central pigmentation of brown and borders colored in shades of beige. There were significant differences among the average dimensions of micro- and macroconidia on PDA, AM, and SN. The pathogenicity was confirmed for all isolates despite of different morphophysiological characteristics. There was no correlation among isolates morphophysiological variability, virulence, and geographical origin. Key words: Malus domestica L., culture medium, mycelial and conidial morphophysiology.
\end{abstract}

\footnotetext{
Cancro europeu da macieira: variabilidade morfofisiológicas e patogenicidade de isolados de Neonectria ditissima no sul do Brasil
}

RESUMO: O cancro europeu (CE) da macieira é causado pelo fungo Neonectria ditissima e foi oficialmente registrado como praga quarentenária em 2012. Foram avaliados 35 isolados de $N$. ditissima provenientes de ramos de macieira com sintomas típicos de CE de diferentes regiões do sul do Brasil. Os isolados foram identificados pelos primers especificos Ch1 e Ch2 e analisados quanto as características morfofisiológicas e virulência na cultivar de macieira Gala. Os sintomas foram caracterizados e os isolados comparados com base no crescimento micelial médio (CMM), indice de crescimento micelial (ICM), coloração das colonias e tipos, dimensões e produção de conídios em meios de cultura batata-dextrose-ágar (BDA), malte-ágar (MA) e meio sintético SNAY (SS). Dezenove isolados tiveram os maiores CMM sobre BDA, formando três grupos de crescimento de 35.56 (GI), 52.71 (GII) e 62.67mm (GIII). Sete isolados tiveram ICM maior de 4mm de diâmetro sobre BDA quando comparados com os meios MA e SS. A maior produção de conídios ocorreu sobre o meio SS e a coloração predominante foi de branco-à-bege com pigmentação central marrom e bordas de colônia em tons de bege. Foram observadas diferenças significativas nas dimensões médias dos micro- e macroconídios sobre os meios de culturas BDA, MA e SS. Todos os isolados foram patogênicos na cultivar de macieira gala, independentemente das diferenças morfofisiológicas. Não foram observadas correlações entre a variabilidade morfofisiológicas, virulência e origem geográfica dos isolados.

Palavras-chave: Malus domestica, meios de culturas, morfofisiologia de micélios e conídios.

\section{INTRODUCTION}

Neonectria ditissima (Tul. \& C. Tul.) [anamorph Cylindrocarpon heteronema (Berk. \& Broome)] is the causal agent of European canker (EC) in apple [Malus domestica (Borkh.) Borkh.] (CASTLEBURY et al., 2006; CHAVERRI et al., 2011; WEBER, 2014). The causal agent was originally named Nectria ditissima in 1865 (FLACK \& SWINBURNE, 1977) and is already well spread worldwide (SANHUEZA, 1998; BOGO et al., 2008). In Brazil, EC was first reported in a nursery in Vacaria municipality in the state of Rio Grande do Sul at 1998 (SANHUEZA, 1998). In the absence of disease inspection and management, EC was spread through infected commercial seedling to Rio Grande do Sul, Santa Catarina and Parana States, and only in 2012 was EC caused by $N$. ditissima officially registered by the Brazilian Agriculture, Livestock and Supply Ministry (MAPA) as a quarantine pest (BRASIL, 2013).

N. ditissima infection occurs via natural as well as pruning-induced wounds, foliar abscission, bud-base entrance, and/or grafting, and may occur throughout the year. Also, N. ditissima can cause fruit 
calyx infection at the beginning of the growing season and/or pre- or postharvest fruit calyx decay. The first trunk or branch symptoms are reddish to dark-brown spots in the bark. These lesions increase in size, developing into a wood tissue slump, and form a canker with exposure of internal tissue (SANHUEZA, 1998). These cankers can be used as infection routes for secondary pathogens that exacerbate the disease (BRAYFORD et al., 2004). EC symptoms in apple fruits begin as dark lesions near the floral apparatus followed by a red pigmentation around the calyx. The fruit rot is brown, superficial, and with dry texture or cork, and fruiting bodies can usually be found under high relative humidity (LANGRELL, 2002; CHAVERRI et al., 2011).

The pathogen overwinters as ascospores in perithecia (SANHUEZA, 1998). Although macroconidia are highly infectious, the epidemiological role of microconidia is uncertain (WEBER, 2014). Morphological variation in Neonectria resulted in the subdivision of species into five informal groups, mostly based on perithecial characteristics, as $N$. coccinea/ galligena-group, N. mammoidea-group, N. rugulosa group, $N$. radicicola-group, and $N$. veuillotiana-group. However, species that have been placed in Neonectria and species of Nectria having a Cylindrocarpon anamorph vary greatly in the morphology of their perithecia and degrees of ascospore ornamentation. Some species of Neonectria are similar in perithecial morphology with differences seen only in the anamorph (CHAVERRI et al., 2011).

Ascospores of $N$. ditissima are ellipsoidal, one-septate, and slightly constricted at the septum. Ripe perithecia may be identified by a whitish cirrus of ascospores (WEBER, 2014). Two types of conidia are produced in nature and in culture. Macroconidia are straight or slightly curved and often 5-septate, although on agar there may be predominantly 1 - to 3 -septate forms. Microconidia are short-cylindrical or ellipsoidal and aseptate or 1-septate. It is difficult to distinguish microconidia from immature macroconidia (BOOTH, 1966; WEBER, 2014). FLACK \& SWINBURNE (1977) had noted differences in both host range and symptoms produced by Nectria spp. from different source hosts. BARNARD et al. (1988) indicated no substantive intraspecific variability with respect to spore morphology among many $N$. galligena isolates. Additionally, they suggested little evidence of host specificity among isolates because all isolates were pathogenic to different hosts.

There are no references to EC disease or $N$. ditissima characterization in Brazil. Thus, the purpose of this study was the morphophysiological characterization of 35 isolates of $N$. ditissima in different culture media and their pathogenicity on 3-year-old Gala apple trees in southern Brazil.

\section{MATERIALS AND METHODS}

\section{Isolates and inoculum production}

Branches of the Gala apple cultivar with typical EC symptoms were collected from 12 and 23 commercial orchards in Santa Catarina State (Água Doce/SC municipality: $26^{\circ} 59^{\prime} 52^{\prime \prime} \mathrm{S}, 51^{\circ}$ 33' 22" W) and Rio Grande do Sul State (Vacaria/ RS municipality: $28^{\circ} 30^{\prime} 44^{\prime \prime} \mathrm{S}, 50^{\circ} 56^{\prime} 02^{\prime \prime} \mathrm{W}$ ), respectively. Fragments of epidemic tissue branches were disinfected with 92 ethyl alcohol, placed in acidified potato dextrose agar (PDA) medium in Petri dishes, and incubated in a biochemical oxygen demand (BOD) chamber under a $24 \mathrm{~h}$ light photoperiod at $20 \pm 0.5^{\circ} \mathrm{C}$. The 35 pure colonies were gently scraped with a scalpel to remove the sporodochia and agitated in test tubes containing $5 \mathrm{~mL}$ of sterile distilled water (SDW) plus one drop of Tween 80. The suspensions were filtered through gauze and the concentrations of conidia were measured with a Neubauer chamber and adjusted to $1 \times 10^{4}$ conidia $\mathrm{mL}^{-1}$. A $1 \mathrm{~mL}$ aliquot of each spore solution was placed on PDA in a Petri dish and incubated in a BOD chamber for 5 days under a $24 \mathrm{~h}$ light photoperiod at $22 \pm 0.5^{\circ} \mathrm{C}$. Mycelium plugs (5mm diameter) from single-spore cultures of the isolates were transferred to PDA test tubes, incubated under the same conditions, and stored at $4^{\circ} \mathrm{C}$. The 35 isolates were identified by the Agronômica laboratory (Laboratório de Diagnóstico Fitossanitário e Consultoria - NIRE 43.205.056.551) using a pair of Ch1 (5'-AAC CCC TGT GAA CAT ACC CAT C-3') and Ch2 (5'-GTG GCC GCG CTG CTC TTC CG3') specific primers plus SYBR-Green and designed from comparisons of the internal transcribed spacer (ITS) regions as $N$. ditissima.

\section{Colonies and conidia characterization}

The $35 \mathrm{~N}$. ditissima isolates were evaluated for average mycelium growth (AMG), mycelium growth index (MGI), colony color, conidia type, dimension, and sporulation in three culture media: potato-dextrose-agar (PDA), malt extract agar (MA), and SNAY synthetic (SN). Mycelial plugs $(5 \mathrm{~mm}$ diameter) from 12-day-old cultures of the 35 isolates were placed in the centers of Petri dishes containing PDA and incubated in a BOD for 12 days under a $24 \mathrm{~h}$ light photoperiod at $22 \pm 0.5^{\circ} \mathrm{C}$. Colony diameter was assessed in two different ways every $24 \mathrm{~h}$ by digital pachymeter by orthogonal dimension and by two 
perpendicular dimensions. Results were converted to AMG $\left(\mathrm{mm} \mathrm{h}^{-1}\right)$ according to LEHNER et al. (2014) and MGI according to the adapted formula described by MAGUIRE (1962). Isolates with AMG values $\geq 60.0 \mathrm{~mm}$ were assigned as the highest-myceliumgrowth group at the end of the evaluation time. The experiment was performed twice. MGI values $\geq 4.0 \mathrm{~mm}$ were assigned as the largest interaction between isolates and culture media. The experiments followed a completely randomized $3 \times 35$ factorial design (three culture media and 35 isolates) with five replicates per isolate in each culture medium. A colony growing in a plate was treated as an experimental unit. Central and border colony color (mycelium color in the adaxial and abaxial Petri dish) and pigmentation were visually evaluated using the Pantone ${ }^{\circledR}$ color standard range after 12 days of incubation. The $35 \mathrm{~N}$. ditissima isolates were cultured on PDA, AM, and SN culture media during 20 days under a $24 \mathrm{~h}$ light photoperiod at $22 \pm 0.5^{\circ} \mathrm{C}$ until sporodochia formation. One sporodochium was macerated in $5 \mathrm{~mL}$ of SDW with one drop of Tween 80 and the conidial concentration was measured with a Neubauer chamber to estimate conidia production (sporulation). The experiments followed a completely randomized design with five replicates per isolate in each culture medium.

\section{Conidial morphology}

Conidial morphology on PDA, AM and SN culture media was assessed by the length and width of 50 conidia of each isolate on each medium. Measurements were converted to micrometers $(\mu \mathrm{m})$. The experiments followed a completely randomized $3 \times 35$ factorial design (three culture media and 35 isolates) with four replicates per isolate in each medium. The data were transformed for analysis of variance by addition of 0.5 to each data point.

\section{Pathogenicity testin}

The EC symptoms were reproduced by inoculation of 3-year-old Gala apple cultivar plants in $10 \mathrm{~L}$ pots filled with soil and organic matter. Five buds from different plant were removed with a scalpel and replaced with $5.0 \mathrm{~mm}$ PDA mycelium plugs of the $35 \mathrm{~N}$. ditissima isolates and covered with adhesive tape. The control test was inoculated with a $5.0 \mathrm{~mm}$ pure PDA plug. Plants were kept in a climate chamber with $12 \mathrm{~h}$ light photoperiod at $22 \pm 0.5^{\circ} \mathrm{C}$ for 14 days. The symptoms were evaluated by visual assessment of typical EC symptoms. The experiments followed a completely randomized design with four replicates of one plant with five experimental wounds.

\section{Statistical analyses}

Data for all experiments were analyzed by analysis of variance using ASSISTAT 7.7 Beta (SAS Institute Inc., Cary, NC) to determine the significance of treatment effects. When effects were significant, the means were analyzed by the Scott Knock test.

\section{RESULTS}

Colony characterization and conidia production in different culture media

There were significant differences in mycelium growth among the $35 \mathrm{~N}$. ditissima isolates and among the PDA, AM, and SN culture media. The majority of isolates belonged to group II, which included isolates with AMG of 40.00-59.99m (Table 1). Seven (NR02, NR03, NR05, and NR10), three (NR02, CPi02 and FROL08), and two (CPi06 and CPi17) isolates showed growth over $60.0 \mathrm{~mm}$ diameter in PDA, AM, and $\mathrm{SN}$, respectively. Seven isolates (NR02, NR03, NR10, FR04, AD07, FROL08, and FROL09) showed the highest MGI (MGI $>4.0 \mathrm{~mm}$ ) on the PDA culture medium and the MGI were statistically different compared with that on AM and SN culture media (Table 1). Five of seven isolates with highest AMG also showed the highest MGI (Table 1). The AM culture medium showed no isolates with MGI greater than $4.0 \mathrm{~mm}$ diameter (Table 1). There were significant differences $(P<0.05)$ in the macro- and microconidia production of the $35 \mathrm{~N}$. ditissima isolates on PDA, AM, and SN (Table 1). Sporulation was higher $\left(73.7 \times 10^{4}\right.$ conidia sporodochium $\left.{ }^{-1}\right)$ on SN than on PDA or AM. The CPi09, AD06, and AD10 isolates showed the highest conidial production on PDA, SN, and AM, respectively (Table 1). PDA was the only medium that showed the formation of three growth groups (group I, 20.00-39.99mm; group II, 40.00-59.99mm; and group III, $\geq 60.00 \mathrm{~mm}$ ) based on the AMG (Table 2). There was broad variation in colony color and aspect in the $N$. ditissima isolates on PDA, AM and SN culture media. The colonies showed smooth borders and little aerial mycelium to slightly cottony mycelium in the three culture media. Some colonies showed dense aerial mycelium and flocculates with the presence of concentric zones. Aerial mycelium color varied from white through tones of beige to orange-brown. There were a formation of four different colony color group (group A, B, C, and D) on PDA culture medium, according to the Pantone ${ }^{\circledR}$ color scale (Table 3). Colonies were white, pale cream, and light orange with tones of beige or without borders and fluffy on plain PDA but produce soluble beige, yellowish to brown with white, beige or orange borders (Table 3). Colony color varied from white to light beige, with absent borders and pigmentation in tons of white, 
Table 1 - Average mycelium growth (AMG), mycelium growth index (MGI) and average sporulation on the three different culture media of the 35 Neonectria ditissima isolates from five orchards of Gala apple cultivar of two regions of southern Brazil after 20 days of incubation under $24 \mathrm{~h}$ light photoperiod at temperature of $22^{\circ} \mathrm{C} \pm 0.5^{\circ} \mathrm{C}$.

\begin{tabular}{|c|c|c|c|c|c|c|c|c|c|}
\hline \multirow{3}{*}{ Isolates } & \multicolumn{3}{|c|}{ 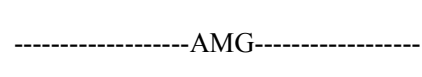 } & -------- & ----MGI--- & --------- & \multicolumn{3}{|c|}{$\begin{array}{l}\text { Average sporulation (conidia x } 10^{4} \\
\text { sporodochium }^{-1} \text { ) }\end{array}$} \\
\hline & \multicolumn{9}{|c|}{ 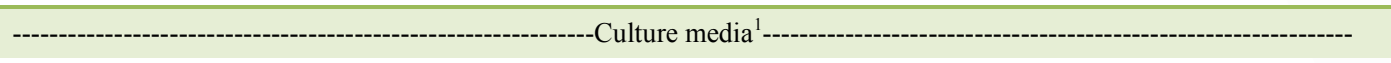 } \\
\hline & $\mathrm{BDA}^{1}$ & $\mathrm{SN}^{2}$ & $\mathrm{AM}^{3}$ & BDA & SN & AM & BDA & $\mathrm{SN}$ & $\mathrm{AM}$ \\
\hline NR02 & $60.32 b^{*}$ & $63.94 \mathrm{a}$ & $39.75 \mathrm{~m}$ & $4.06 \mathrm{cB}$ & $4.29 \mathrm{bA}$ & $2.39 \mathrm{iC}$ & $6.25 \mathrm{eA}$ & $0.00 \mathrm{fB}$ & $6.25 \mathrm{eA}$ \\
\hline NR03 & $67.89 \mathrm{a}$ & $59.13 \mathrm{c}$ & $59.20 \mathrm{c}$ & $4.61 \mathrm{aA}$ & $3.84 \mathrm{~dB}$ & $3.89 \mathrm{aB}$ & $18.75 \mathrm{cB}$ & $35.00 \mathrm{bA}$ & $15.00 \mathrm{~dB}$ \\
\hline NR05 & $62.68 b$ & $43,73 \mathrm{j}$ & $38,79 \mathrm{~m}$ & $3,95 \mathrm{dA}$ & $2,53 \mathrm{iB}$ & $2,25 \mathrm{iC}$ & $2,00 \mathrm{fB}$ & $21,25 \mathrm{cA}$ & $22,50 \mathrm{cA}$ \\
\hline NR10 & $61,08 b$ & $52,54 \mathrm{f}$ & $50,16 \mathrm{~g}$ & $4,30 \mathrm{bA}$ & $3,88 \mathrm{~dB}$ & $3,53 \mathrm{dC}$ & $12,5 \mathrm{dA}$ & $20,2 \mathrm{cA}$ & $17,5 \mathrm{dA}$ \\
\hline FR04 & $60,32 b$ & $48,40 \mathrm{~h}$ & $52,58 \mathrm{f}$ & $4,09 \mathrm{cA}$ & $3,02 \mathrm{gC}$ & $3,40 \mathrm{eB}$ & $9,0 \mathrm{eB}$ & $15,0 \mathrm{dA}$ & $20,0 \mathrm{cA}$ \\
\hline FR10 & $44,63 \mathrm{j}$ & $54,40 \mathrm{e}$ & $49,83 \mathrm{~g}$ & $2,97 \mathrm{iC}$ & $3,77 \mathrm{dA}$ & $3,20 \mathrm{fB}$ & $31,2 \mathrm{bA}$ & $16,2 \mathrm{~dB}$ & $10,0 \mathrm{eB}$ \\
\hline FR14 & $56,90 \mathrm{~d}$ & $49,19 \mathrm{~g}$ & 41,641 & $3,64 \mathrm{eA}$ & $3,08 \mathrm{gB}$ & $2,43 \mathrm{iC}$ & $12,5 \mathrm{~dB}$ & $38,7 \mathrm{bA}$ & $15,0 \mathrm{~dB}$ \\
\hline FR15 & $46,53 \mathrm{i}$ & $54,30 \mathrm{e}$ & $46,12 \mathrm{i}$ & $3,09 \mathrm{hB}$ & $3.70 \mathrm{dA}$ & $3.10 \mathrm{gB}$ & $21.2 \mathrm{cA}$ & $26.2 \mathrm{cA}$ & $11.2 \mathrm{~dB}$ \\
\hline CPi01 & $46.21 \mathrm{i}$ & $55.29 \mathrm{~d}$ & $58.46 \mathrm{c}$ & $3.09 \mathrm{hA}$ & $1.68 \mathrm{mC}$ & $2.06 \mathrm{jB}$ & $0.00 \mathrm{gC}$ & $55.0 \mathrm{aA}$ & $40.0 \mathrm{bB}$ \\
\hline CPi02 & $59.76 c$ & $61.97 \mathrm{~b}$ & $57.06 \mathrm{~d}$ & $2.22 \mathrm{lB}$ & $3.24 \mathrm{fA}$ & $1.81 \mathrm{lC}$ & $8.7 \mathrm{eB}$ & $0.00 \mathrm{fC}$ & $33.7 \mathrm{cA}$ \\
\hline $\mathrm{CPi03}$ & $36.63 n$ & $38.14 n$ & $39.89 \mathrm{~m}$ & $3.32 \mathrm{gA}$ & $2.43 \mathrm{iB}$ & $2.29 \mathrm{iB}$ & $3.7 \mathrm{fA}$ & $0.00 \mathrm{fB}$ & $6.2 \mathrm{eA}$ \\
\hline CPi05 & $32.23 \mathrm{p}$ & $49.45 \mathrm{~g}$ & $49.11 \mathrm{~g}$ & $3.12 \mathrm{hB}$ & $3.33 \mathrm{fA}$ & $2.04 \mathrm{jC}$ & $45.0 \mathrm{aA}$ & $60.0 \mathrm{aA}$ & $22.5 \mathrm{cB}$ \\
\hline CPi06 & $37.14 n$ & $39.02 \mathrm{~m}$ & $62.08 \mathrm{~b}$ & $3.41 \mathrm{fA}$ & $2.49 \mathrm{iB}$ & $2.33 \mathrm{iC}$ & $7.5 \mathrm{eA}$ & $0.00 \mathrm{fB}$ & $8.75 \mathrm{eA}$ \\
\hline CPi09 & $58.61 \mathrm{c}$ & $37.80 \mathrm{n}$ & $56.35 d$ & $3.27 \mathrm{gA}$ & $3.37 \mathrm{fA}$ & $2.49 \mathrm{hB}$ & $47.5 \mathrm{aA}$ & $16.2 \mathrm{~dB}$ & $16.2 \mathrm{~dB}$ \\
\hline CPi10 & $35.28 \mathrm{o}$ & 34.920 & $49.49 \mathrm{~g}$ & $3.21 \mathrm{gA}$ & $2.14 \mathrm{lB}$ & $1.941 \mathrm{lC}$ & $16.2 \mathrm{dA}$ & $0.00 \mathrm{fB}$ & $0.00 \mathrm{gB}$ \\
\hline CPi14 & $64.35 \mathrm{a}$ & $48.52 \mathrm{~h}$ & $58.04 \mathrm{c}$ & $2.82 \mathrm{iC}$ & $3.41 \mathrm{eB}$ & $3.73 \mathrm{bA}$ & $0.00 \mathrm{gB}$ & $27.5 \mathrm{bA}$ & $0.00 \mathrm{gB}$ \\
\hline CPi16 & 41.441 & $49.93 \mathrm{~g}$ & $55.47 \mathrm{~d}$ & $3.95 \mathrm{~dB}$ & $4.55 \mathrm{aA}$ & $3.62 \mathrm{cC}$ & $33.7 \mathrm{bB}$ & $48.7 \mathrm{aA}$ & $25.0 \mathrm{cB}$ \\
\hline CPi17 & $37.83 n$ & $56.96 \mathrm{~d}$ & $61.36 \mathrm{~b}$ & $2.10 \mathrm{mB}$ & $2.31 \mathrm{jA}$ & $2.30 \mathrm{iA}$ & $16.2 \mathrm{dA}$ & $12.5 \mathrm{~dB}$ & $10.0 \mathrm{~dB}$ \\
\hline AD03 & $50.32 \mathrm{~g}$ & $32.15 p$ & $36.42 n$ & $2.06 \mathrm{mC}$ & $2.91 \mathrm{hB}$ & $3.07 \mathrm{gA}$ & $23.7 \mathrm{cB}$ & $41.2 \mathrm{bA}$ & $20.0 \mathrm{cB}$ \\
\hline AD04 & 34.260 & $46.79 \mathrm{i}$ & $29.69 p$ & $2.251 \mathrm{C}$ & $2.45 \mathrm{iB}$ & $3.94 \mathrm{aA}$ & $21.2 \mathrm{cA}$ & $28.7 \mathrm{bA}$ & $10.0 \mathrm{eB}$ \\
\hline AD05 & $53.30 \mathrm{e}$ & 42.361 & $39.15 \mathrm{~m}$ & $3.71 \mathrm{eA}$ & $2.36 \mathrm{jC}$ & $3.45 \mathrm{~dB}$ & $0.00 \mathrm{gC}$ & $24.2 \mathrm{cA}$ & $10.0 \mathrm{eB}$ \\
\hline AD06 & $44.75 \mathrm{j}$ & $47.55 \mathrm{~h}$ & $32.44 \mathrm{p}$ & $2.28 \mathrm{lB}$ & $2.25 \mathrm{jB}$ & $3.01 \mathrm{gA}$ & $21.2 \mathrm{cA}$ & 73.7aA & $16.2 \mathrm{dA}$ \\
\hline AD07 & $54.35 \mathrm{e}$ & 41.631 & $39.59 \mathrm{~m}$ & $4.16 \mathrm{cA}$ & $2.91 \mathrm{hC}$ & $3.65 \mathrm{cB}$ & $18.7 \mathrm{cA}$ & $15.0 \mathrm{dA}$ & $13.7 \mathrm{dA}$ \\
\hline AD08 & $47.44 \mathrm{~h}$ & $48.65 \mathrm{~h}$ & $38.15 n$ & $2.48 \mathrm{jC}$ & $2.88 \mathrm{hB}$ & $3.46 \mathrm{dA}$ & $13.7 \mathrm{~dB}$ & $25.0 \mathrm{cA}$ & $11.2 \mathrm{~dB}$ \\
\hline $\mathrm{AD} 10$ & $51.62 \mathrm{f}$ & $37.81 n$ & $33.94 \mathrm{o}$ & $2.331 \mathrm{C}$ & $3.50 \mathrm{eB}$ & $3.87 \mathrm{aA}$ & $43.7 \mathrm{aA}$ & $33.7 \mathrm{bA}$ & $50.0 \mathrm{aA}$ \\
\hline FROL01 & $52.82 \mathrm{f}$ & 41.181 & $37.24 n$ & $3.40 \mathrm{fA}$ & $2.43 \mathrm{iB}$ & $2.21 \mathrm{jC}$ & $15.0 \mathrm{~dB}$ & $38.7 \mathrm{bA}$ & $7.5 \mathrm{eC}$ \\
\hline FROL02 & $55.25 \mathrm{~d}$ & $43.58 \mathrm{j}$ & $38.37 \mathrm{~m}$ & $3.44 \mathrm{fA}$ & $2.49 \mathrm{iB}$ & $2.15 \mathrm{jC}$ & $18.7 \mathrm{cA}$ & $21.2 \mathrm{cA}$ & $15.0 \mathrm{dA}$ \\
\hline FROL03 & $53.13 \mathrm{e}$ & 40.841 & $38.01 \mathrm{n}$ & $3.44 \mathrm{fA}$ & $2.52 \mathrm{iB}$ & $2.26 \mathrm{iC}$ & $7.5 \mathrm{eB}$ & $21.2 \mathrm{cA}$ & $6.2 \mathrm{eB}$ \\
\hline FROL04 & $55.76 \mathrm{~d}$ & 34.550 & 34.410 & $3.62 \mathrm{eA}$ & $1.98 \mathrm{lB}$ & $2.07 \mathrm{jB}$ & $11.2 \mathrm{dA}$ & $8.2 \mathrm{dA}$ & $13.7 \mathrm{dA}$ \\
\hline FROL05 & $59.38 \mathrm{c}$ & $51.24 \mathrm{f}$ & $44.43 \mathrm{j}$ & $3.74 \mathrm{eA}$ & $3.07 \mathrm{gB}$ & $2.67 \mathrm{hC}$ & $15.0 \mathrm{dA}$ & $14.0 \mathrm{dA}$ & $0.00 \mathrm{gB}$ \\
\hline FROL06 & $56.81 d$ & $38.73 \mathrm{~m}$ & $36.75 n$ & $3.60 \mathrm{eA}$ & $2.18 \mathrm{lB}$ & $2.15 \mathrm{jB}$ & $21.5 \mathrm{cA}$ & $30.0 \mathrm{bA}$ & $27.5 \mathrm{cA}$ \\
\hline FROL07 & $54.11 \mathrm{e}$ & $47.48 \mathrm{~h}$ & 42.041 & $3.44 \mathrm{fA}$ & $2.96 \mathrm{hB}$ & $2.55 \mathrm{hC}$ & $4.2 \mathrm{fA}$ & $6.2 \mathrm{eA}$ & $3.0 \mathrm{fA}$ \\
\hline FROL08 & $62.02 b$ & $61.56 b$ & $48.26 \mathrm{~h}$ & $4.19 \mathrm{cA}$ & $4.16 \mathrm{bA}$ & $3.07 \mathrm{gB}$ & $6.5 \mathrm{eB}$ & $15.0 \mathrm{dA}$ & $11.2 \mathrm{dA}$ \\
\hline FROL09 & $58.84 \mathrm{c}$ & $59.22 \mathrm{c}$ & $48.23 \mathrm{~h}$ & $4.04 \mathrm{cA}$ & $4.02 \mathrm{cA}$ & $3.22 \mathrm{fB}$ & $22.5 \mathrm{cA}$ & $20.0 \mathrm{cA}$ & $14.0 \mathrm{dA}$ \\
\hline FROL10 & $57.63 c$ & $55.47 d$ & $48.28 \mathrm{~h}$ & $3.91 \mathrm{dA}$ & $3.71 \mathrm{~dB}$ & $3.09 \mathrm{gC}$ & $0.00 \mathrm{gB}$ & $11.2 \mathrm{dA}$ & $13.7 \mathrm{dA}$ \\
\hline CV \% & & 2.71 & & & 3.5 & & & 13.87 & \\
\hline
\end{tabular}

${ }^{1} \mathrm{PDA}=$ potato-dextrose-agar; $\mathrm{SN}^{2}=$ synthetic SNAY; $\mathrm{AM}^{3}=$ malt extract agar. ${ }^{*}$ Means followed by the same small letter in the column and the capital letter in the row are not significantly different by Scott-Knock test $(\mathrm{P}<0.05)$. 
Table 2 - The distribution of the 35 Neonectria ditissima isolates in groups according to ascending order of average mycelium growth (AMG) on potato-dextrose-agar medium after 20 days of incubation under $24 \mathrm{~h}$ light photoperiod at temperature of $22^{\circ} \mathrm{C} \pm 0.5^{\circ} \mathrm{C}$.

\begin{tabular}{|c|c|c|c|}
\hline Size groups (mm) & Isolates & AMG & Groups AMG average (mm) \\
\hline \multirow{6}{*}{$\begin{array}{l}\text { Group I } \\
20.00-39.99\end{array}$} & CPi05 & $32.23 \mathrm{p}$ & \multirow{6}{*}{35.56} \\
\hline & AD04 & $34.26 \mathrm{o}$ & \\
\hline & CPi10 & $35.28 \mathrm{o}$ & \\
\hline & $\mathrm{CPi03}$ & $36.63 n$ & \\
\hline & CPi06 & $37.14 \mathrm{n}$ & \\
\hline & CPi17 & $37.83 \mathrm{~m}$ & \\
\hline \multirow{22}{*}{$\begin{array}{l}\text { Group II } \\
40.00-59.99\end{array}$} & CPi16 & 41.441 & \multirow{29}{*}{52.71} \\
\hline & FR10 & $44.63 \mathrm{j}$ & \\
\hline & AD06 & $44.75 \mathrm{j}$ & \\
\hline & $\mathrm{CPi} 01$ & $46.21 \mathrm{i}$ & \\
\hline & FR15 & $46.53 \mathrm{i}$ & \\
\hline & AD08 & $47.44 \mathrm{~h}$ & \\
\hline & $\mathrm{AD} 03$ & $50.32 \mathrm{~g}$ & \\
\hline & $\mathrm{AD} 10$ & $51.62 \mathrm{f}$ & \\
\hline & FROL01 & $52.82 \mathrm{f}$ & \\
\hline & FROL03 & $53.13 \mathrm{e}$ & \\
\hline & AD05 & $53.30 \mathrm{e}$ & \\
\hline & FROL07 & $54.11 \mathrm{e}$ & \\
\hline & $\mathrm{AD} 07$ & $54.35 \mathrm{e}$ & \\
\hline & FROL02 & $55.25 \mathrm{~d}$ & \\
\hline & FROL04 & $55.76 \mathrm{~d}$ & \\
\hline & FROL06 & $56.81 \mathrm{~d}$ & \\
\hline & FR14 & $56.90 \mathrm{~d}$ & \\
\hline & FROL10 & $57.63 \mathrm{c}$ & \\
\hline & $\mathrm{CPi} 09$ & $58.61 \mathrm{c}$ & \\
\hline & FROL09 & $58.84 \mathrm{c}$ & \\
\hline & FROL05 & $59.38 \mathrm{c}$ & \\
\hline & $\mathrm{CPi} 02$ & $59.76 \mathrm{c}$ & \\
\hline \multirow{7}{*}{ Group III >60.00 } & FR04 & $60.32 \mathrm{~b}$ & \\
\hline & NR02 & $60.32 \mathrm{~b}$ & \\
\hline & NR10 & $61.08 \mathrm{~b}$ & \\
\hline & FROL08 & $62.02 \mathrm{~b}$ & \\
\hline & NR05 & $62.68 \mathrm{~b}$ & \\
\hline & CPi14 & $64.35 \mathrm{a}$ & \\
\hline & NR03 & $67.89 \mathrm{a}$ & \\
\hline
\end{tabular}

Means followed by the same small letter are not significantly different by Scott Knock test $(\mathrm{P}<0.05)$. 
Table 3 - Distribution of the 35 Neonectria ditissima isolates in groups accordance to colony color, border and culture medium pigmentation according to the Pantone ${ }^{\circledR}$ color scale on potato-dextrose-agar medium after 20 days of incubation under $24 \mathrm{~h}$ light photoperiod at temperature of $22^{\circ} \mathrm{C} \pm 0.5^{\circ} \mathrm{C}$.

\begin{tabular}{lcccc}
\hline Groups & Isolates & Colony color & Border & Pigmentation \\
\hline A & NR02, NR03, NR10, CPi02 & White & Absent & \multicolumn{2}{c}{ Tones of yellow } \\
& FR04, FR10, FR14, FR15, CPi01, CPi05, & & Brown with edges in tones \\
B & CPi06, CPi09, Cpi16, Cpi17, AD03, AD04, & Tones of beige & Tones of beige & \\
& AD06, FROL03, FROL04, FROL 05, & & & \\
C & FROL07, FROL08, FROL09, FROL10 & & Absent \\
D & CPi03, CPi10, FROL01, FROL06, AD05 & White to tones of beige & Tones of beige \\
\hline
\end{tabular}

beige, and yellow on AM culture medium, and colony color and pigmentation in tones of translucent white on SN culture medium. Three distinct color groups were formed in PDA, according to the Pantone ${ }^{\circledR}$ color scale. The largest group B, with 15 isolates, showed colony color in tones of beige and brown pigmentation with borders in tones of beige (Table 3).

\section{Conidia morphology, size and pathogenicity testing}

All $N$. ditissima isolates produced microand macroconidia in at least one of the culture media evaluated. There were significant differences among the average dimensions of micro- and macroconidia on PDA, AM, and SN Table 4). The three media produced macroconidia that were slightly curved, hyaline, and multicellular varying from 1 (immature conidia) to 7 septa, with rounded extremities and dimensions varying in the range 9.5-11.0x48.3-69.8 $\mu \mathrm{m}$. Microconidia were straight, elliptic to cylindrical, hyaline, and unicellular, with dimensions varying in the range 4.5-6.8x30.9$44.2 \mu \mathrm{m}$. The average micro- and macroconidia length and width on PDA, AM, and SN were $35.4 \times 4.8$, $35.2 \times 5.2$, and $34.8 \times 5 \mu \mathrm{m}$ and $63.5 \times 10.1,62.3 \times 10.6$, and $59.7 \times 10.3 \mu \mathrm{m}$, respectively (Table 4 ). The largest micro- and macroconidia were produced on the AM and SN culture media; however, with no significant differences between the media (Table 4). All $35 \mathrm{~N}$. ditissima isolates were pathogenic to 3-year-old Gala apple cultivar plants despite of isolates origin and virulence groups were not observed after 20 days postinoculation. Within 8-12 days after inoculation, most plants began to exude clear to amber-colored gum droplets at the points of inoculation. This host response was exhibited by plants inoculated with each of the 35 $N$. ditissima and lacking in the control inoculations. Most of the young branches began to show the first symptoms of swallow elliptical point with an exposure of bark internal tissue typical of canker after 12-14 days after $N$. ditissima isolates inoculation. Cankers showed a reddish-brown spot around a leaf scar, spur, and bark. Young cankers produced small, whitish sporodochial fruiting bodies after 14 days after $N$. ditissima isolates inoculation. Over time, all inoculated plants displayed varying degrees of bark tissue discoloration/ necrosis, bark fissuring, and/or stem deformation at or near the points of artificial inoculation. Comparable symptoms were lacking in control inoculations.

\section{DISCUSSION}

European canker is an important and recent quarantine pest in Brazil that demands special attention to the correct characterization and pathogenicity test of the isolates populations present in southern Brazil. Our data indicate no substantive intraspecific variability with respect to spore morphophysiological parameters among 35 $N$. ditissima isolates collected from different apple orchards in Rio Grande do Sul and Santa Catarina States. They also suggested little evidence of host specificity among isolates, given that all isolates were pathogenic to the Gala apple cultivar. These results parallel reported that morphophysiological isolates of $N$. ditissima were capable of infecting the most popular and wide spread cultivar in southern Brazil, giving a confident interpretation that the 35 isolates belonging to the same group or variety.

One of the objectives of the study was to the comparison of the influences of three different media, including synthetic, semi-synthetic, and natural on the growth of $N$. ditissima. The fungus grew on all culture media tested. However, natural solid media were more favorable for growth. The differences observed in the AMG and MGI of the isolates on PDA, AM, and SN may have been due to qualitative and quantitative aspects of these media. PDA has a simple formulation and the highest nutrient contents, supporting the best mycelial growth of the fungus (BOGO et al., 2008; SAHA et al., 2008). The genera Neonectria and Cylindrocarpon usually produce pigmentation with tones of light brown and white borders on potato sucrose agar medium, but on SN medium the colonies 
Table 4 - Microconidia and macroconidia average length and width $(\mathrm{mm})$ of the 35 Neonectria ditissima isolates on different culture media after 20 days of incubation under $24 \mathrm{~h}$ light photoperiod at temperature of $22^{\circ} \mathrm{C} \pm 0.5^{\circ} \mathrm{C}$.

\begin{tabular}{|c|c|c|c|c|c|c|c|c|c|c|c|c|}
\hline \multirow[t]{3}{*}{ Isolates } & \multicolumn{4}{|c|}{ 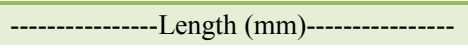 } & \multicolumn{2}{|c|}{--Width (mm)-- } & \multicolumn{3}{|c|}{----------Length (mm)---------- } & \multicolumn{3}{|c|}{--------Width (mm)--------- } \\
\hline & \multicolumn{12}{|c|}{ 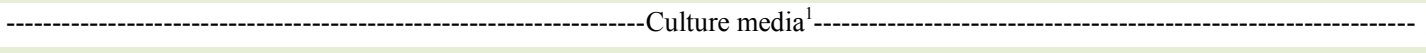 } \\
\hline & PDA & $\mathrm{SN}$ & $\mathrm{AM}$ & PDA & $\mathrm{SN}$ & $\mathrm{AM}$ & PDA & $\mathrm{SN}$ & $\mathrm{AM}$ & PDA & $\mathrm{SN}$ & $\mathrm{AM}$ \\
\hline NR02 & $32.1 \mathrm{eA}^{*}$ & - & - & $4.8 \mathrm{eA}$ & - & - & - & - & $48.3 \mathrm{gA}$ & - & - & $10.0 \mathrm{cA}$ \\
\hline NR03 & $33.0 \mathrm{eA}$ & $33.2 \mathrm{eA}$ & $32.8 \mathrm{fA}$ & $5.0 \mathrm{dA}$ & $5.0 \mathrm{eA}$ & $4.9 \mathrm{dA}$ & - & - & - & - & - & - \\
\hline NR05 & $36.2 \mathrm{cA}$ & - & - & $5.4 \mathrm{cA}$ & - & - & - & $64.7 \mathrm{cA}$ & $62.8 \mathrm{cB}$ & - & $10.7 \mathrm{aA}$ & $10.2 \mathrm{cB}$ \\
\hline NR10 & - & $33.1 \mathrm{eA}$ & - & - & $4.8 \mathrm{eA}$ & - & $62.9 \mathrm{dA}$ & $58.3 \mathrm{eB}$ & $54.7 \mathrm{eC}$ & $10.7 \mathrm{bA}$ & $10.1 \mathrm{bB}$ & $9.6 \mathrm{dC}$ \\
\hline FR04 & $36.6 \mathrm{cA}$ & $30.5 \mathrm{fC}$ & $32.3 \mathrm{fB}$ & $4.9 \mathrm{dA}$ & $4.5 \mathrm{fB}$ & $4.5 \mathrm{eB}$ & - & - & - & - & - & - \\
\hline FR10 & $31.7 \mathrm{eA}$ & $32.3 \mathrm{eA}$ & $30.9 \mathrm{fA}$ & $4.6 \mathrm{eA}$ & $4.5 \mathrm{fA}$ & $4.5 \mathrm{eA}$ & - & - & - & - & - & - \\
\hline FR14 & $32.6 \mathrm{eA}$ & - & - & $5.1 \mathrm{dA}$ & - & - & - & $66.8 \mathrm{bA}$ & $62.4 \mathrm{cB}$ & - & $10.8 \mathrm{aA}$ & $10.2 \mathrm{cB}$ \\
\hline FR15 & $30.5 \mathrm{eA}$ & $31.5 \mathrm{fA}$ & $31.1 \mathrm{fA}$ & $4.5 \mathrm{eA}$ & $4.5 \mathrm{fA}$ & $4.5 \mathrm{eA}$ & - & - & - & - & - & - \\
\hline CPi01 & - & $36.1 \mathrm{dA}$ & $37.1 \mathrm{cA}$ & - & $5.9 \mathrm{cA}$ & $5.2 \mathrm{cB}$ & - & - & - & - & - & - \\
\hline $\mathrm{CPi02}$ & - & - & - & - & - & - & $64.4 \mathrm{cB}$ & - & $69.8 \mathrm{aA}$ & $10.1 \mathrm{~dB}$ & - & $10.5 \mathrm{bA}$ \\
\hline CPi03 & $39.1 \mathrm{bB}$ & - & $41.3 \mathrm{bA}$ & $5.5 \mathrm{cB}$ & - & $5.9 \mathrm{aA}$ & - & - & - & - & - & - \\
\hline $\mathrm{CPi05}$ & $36.3 \mathrm{cA}$ & $33.6 \mathrm{eB}$ & $34.2 \mathrm{eB}$ & $5.5 \mathrm{cA}$ & $5.1 \mathrm{~dB}$ & $5.2 \mathrm{cB}$ & - & - & $55.5 \mathrm{eA}$ & - & - & $10.5 \mathrm{bA}$ \\
\hline CPi06 & - & - & $36.1 \mathrm{dA}$ & - & - & $5.5 \mathrm{bA}$ & $65.8 \mathrm{bA}$ & - & - & $10.4 \mathrm{bA}$ & - & - \\
\hline CPi09 & $39.9 \mathrm{bA}$ & $37.5 \mathrm{cB}$ & - & $5.5 \mathrm{cA}$ & $5.7 \mathrm{cA}$ & - & $64.8 \mathrm{cA}$ & - & $58.6 \mathrm{~dB}$ & $10.5 \mathrm{cA}$ & - & $10.5 \mathrm{bA}$ \\
\hline CPi10 & $33.6 \mathrm{dA}$ & - & - & $5.1 \mathrm{dA}$ & - & - & - & - & - & - & - & - \\
\hline CPi14 & - & $36.8 \mathrm{cA}$ & - & - & $5.4 \mathrm{dA}$ & - & - & - & - & - & - & - \\
\hline CPi16 & $39.8 \mathrm{bB}$ & $32.6 \mathrm{eC}$ & $42.3 \mathrm{aA}$ & $5.5 \mathrm{cB}$ & $4.9 \mathrm{eC}$ & $6.0 \mathrm{aA}$ & - & - & - & - & - & - \\
\hline CPi17 & $36.9 \mathrm{cA}$ & $34.5 \mathrm{~dB}$ & $38.1 \mathrm{cA}$ & $5.1 \mathrm{~dB}$ & $5.3 \mathrm{~dB}$ & $5.6 \mathrm{bA}$ & - & - & - & - & - & - \\
\hline AD03 & $37.3 \mathrm{cA}$ & - & $37.9 \mathrm{cA}$ & $6.0 \mathrm{bA}$ & - & $5.7 \mathrm{bB}$ & $66.7 \mathrm{aB}$ & $68.1 \mathrm{aA}$ & - & $9.8 \mathrm{~dB}$ & $11.0 \mathrm{aA}$ & - \\
\hline AD04 & $32.2 \mathrm{eB}$ & $37.1 \mathrm{cA}$ & $36.2 \mathrm{dA}$ & $4.6 \mathrm{eB}$ & $5.7 \mathrm{cA}$ & $5.5 \mathrm{bA}$ & - & - & - & - & - & - \\
\hline AD05 & - & - & - & - & - & - & - & $65.2 \mathrm{cA}$ & $64.8 \mathrm{cA}$ & - & $10.7 \mathrm{aA}$ & $10.7 \mathrm{aA}$ \\
\hline AD06 & $31.5 \mathrm{eA}$ & $30.5 \mathrm{fA}$ & $31.8 \mathrm{fA}$ & $4.5 \mathrm{eA}$ & $4.5 \mathrm{fA}$ & $4.6 \mathrm{eA}$ & - & - & - & - & - & - \\
\hline AD07 & $41.5 \mathrm{aA}$ & - & - & $6.8 \mathrm{aA}$ & - & - & $66.8 \mathrm{aA}$ & $65.0 \mathrm{cB}$ & $66.1 \mathrm{bA}$ & $10.7 \mathrm{bA}$ & $10.7 \mathrm{aA}$ & $11.0 \mathrm{aA}$ \\
\hline AD08 & $34.9 \mathrm{dA}$ & $35.5 \mathrm{dA}$ & $31.2 \mathrm{fB}$ & $5.1 \mathrm{dA}$ & $4.6 \mathrm{fB}$ & $4.5 \mathrm{eB}$ & - & - & - & - & - & - \\
\hline AD10 & $42.5 \mathrm{aA}$ & - & - & $6.0 \mathrm{bA}$ & - & - & $62.9 \mathrm{~dB}$ & $65.0 \mathrm{cA}$ & $64.6 \mathrm{cA}$ & $10.5 \mathrm{cB}$ & $10.8 \mathrm{aA}$ & $10.5 \mathrm{bB}$ \\
\hline FROL01 & - & $42.1 \mathrm{bA}$ & $31.9 \mathrm{fB}$ & - & $6.6 \mathrm{bA}$ & $4.7 \mathrm{~dB}$ & $66.5 \mathrm{aA}$ & $57.6 \mathrm{eB}$ & - & $11.6 \mathrm{aA}$ & $9.9 \mathrm{bB}$ & - \\
\hline FROL02 & $40.8 \mathrm{aB}$ & $45.5 \mathrm{aA}$ & - & $5.6 \mathrm{cB}$ & $6.5 \mathrm{bA}$ & - & - & $54.8 \mathrm{fB}$ & $63.3 \mathrm{cA}$ & - & $10.1 \mathrm{bB}$ & $10.6 \mathrm{bA}$ \\
\hline FROL03 & - & $44.2 \mathrm{aA}$ & $40.3 \mathrm{bB}$ & - & $6.8 \mathrm{aA}$ & $5.6 \mathrm{bB}$ & $65.6 \mathrm{bA}$ & $59.8 \mathrm{~dB}$ & - & $10.9 \mathrm{bA}$ & $10.3 \mathrm{bB}$ & - \\
\hline FROL04 & $34.2 \mathrm{dA}$ & $35.4 \mathrm{dA}$ & $35.5 \mathrm{dA}$ & $5.0 \mathrm{dA}$ & $5.1 \mathrm{dA}$ & $5.2 \mathrm{cA}$ & - & - & - & - & - & - \\
\hline FROL05 & - & - & - & - & - & - & $64.7 \mathrm{cA}$ & $64.8 \mathrm{cA}$ & - & $10.8 \mathrm{bA}$ & $10.7 \mathrm{aA}$ & - \\
\hline FROL06 & - & - & - & - & - & - & $64.9 \mathrm{cA}$ & $60.0 \mathrm{~dB}$ & $64.2 \mathrm{cA}$ & $10.7 \mathrm{bA}$ & $10.4 \mathrm{bB}$ & $10.9 \mathrm{aA}$ \\
\hline FROL07 & $32.6 \mathrm{eA}$ & $30.5 \mathrm{fB}$ & $32.5 \mathrm{fA}$ & $4.9 \mathrm{dA}$ & $4.5 \mathrm{fB}$ & $5.1 \mathrm{cA}$ & - & - & - & - & - & - \\
\hline FROL08 & $39.1 \mathrm{bA}$ & $35.0 \mathrm{~dB}$ & - & $5.8 \mathrm{bA}$ & $4.6 \mathrm{fB}$ & - & - & - & $51.7 \mathrm{fA}$ & - & - & $10.0 \mathrm{cA}$ \\
\hline FROL09 & - & - & $36.2 \mathrm{dA}$ & - & - & $5.6 \mathrm{bA}$ & $52.0 \mathrm{eB}$ & $59.2 \mathrm{dA}$ & $49.6 \mathrm{gC}$ & $10.5 \mathrm{cA}$ & $10.8 \mathrm{aA}$ & $9.5 \mathrm{~dB}$ \\
\hline FROL10 & - & $31.9 \mathrm{eA}$ & $32.0 \mathrm{fA}$ & - & $4.5 \mathrm{fA}$ & $4.5 \mathrm{eA}$ & - & - & - & - & - & - \\
\hline $\mathrm{CV} \%$ & & 3.42 & & & 4.58 & & & 2.31 & & & 4.14 & \\
\hline average & $35.4 \mathrm{c}$ & $35.2 \mathrm{c}$ & $34.8 \mathrm{~d}$ & $4.8 \mathrm{c}$ & $5.2 \mathrm{c}$ & $5.2 \mathrm{c}$ & $63.5 \mathrm{a}$ & $62.3 \mathrm{a}$ & $59.7 b$ & $10.1 \mathrm{a}$ & $10.6 \mathrm{a}$ & $10.3 \mathrm{a}$ \\
\hline $\mathrm{SD}^{2}$ & 3.1 & 3.2 & 3.1 & 0.4 & 0.6 & 0.4 & 2.3 & 3.6 & 5.7 & 0.3 & 0.3 & 0.3 \\
\hline
\end{tabular}

${ }^{1} \mathrm{PDA}=$ potato-dextrose-agar; $\mathrm{SN}=$ synthetic SNAY; AM= Malt extract agar. ${ }^{2}$ Standard deviation. ${ }^{*}$ Means followed by the same small lette in the column and the capital letter in the row are not significantly different by Scott Knock test $(\mathrm{P}<0.05)$. 
were not pigmented (hyaline) and the mycelium was aerial (LANGRELL, 2002). Four distinct color groups were formed in PDA. SN and AM were excellent media for production of large numbers of multi-celled conidia for most isolates. SN showed the lowest $\mathrm{AMG}$ and MGI values but the highest conidial production. Culture media with vegetable extract, plant material, and low carbohydrate content usually stimulate the sporulation of many fungi (NOZAKI et al., 2004). The $N$. ditissima conidial morphology and sporulation in vitro are in agreement with the results of AMPONSAH et al. (2014) who reported that $N$. ditissima conidia produced in vitro had morphological characteristics and pathogenicity similar to those produced in the field. Variation in colony and substrate color, colony border, topography of mycelia, and number of septa on the three different solid media adds information that may be helpful in the taxonomic identification and genetic variability of $N$. ditissima. There is large conidial diversity between the Neonectria and Cylindrocarpon genera (BRAYFORD, 2004; CHAVERRI et al., 2011), with respect to presence or absence of microconidia, macroconidia, chlamydospores, and number of septa. Variation in number of septa can be associated with factors such as nutrition, relative humidity, and temperature (FLACK \& SWINBURNE, 1977). Conidium length and number of septa may vary with glucose, carbon concentration and initial medium $\mathrm{pH}$, nitrogen source, and culture age (HARDING, 1975). The few one septum conidia reported on the three culture media were probably immature conidia. Thus, on the basis of some differences in the conidial morphology and physiological variation, $N$. ditissima can be considered a pathogen with not a large variability. This report has described the use of PDA, AM, and SN culture media to study and produce $N$. ditissima conidia in vitro reliably and on demand for use in infection studies. The conidia produced in this way were equally as pathogenic as those obtained from the field, and the conidia produced on these media resulted in faster development of disease symptoms, which were visible as soon as 14 days after inoculation. Our study also showed that the verification of the efficacy and performance of a selected medium reported in the literature, using well-characterized type and reference strains, is a crucial step before it is adopted for enumeration. This method for production of $N$. ditissima conidia in vitro will be particularly useful for EC resistance research in Brazil. In summary, the present study showed that despite of PCR identification of the 35 isolates as $N$. ditissima, there are morphophysiological variations between them despite them been pathogenic to the Gala apple cultivar. There was no evidence of correlation between isolates virulence and geographical origin. The non-existence of isolates clusters from the two distant geographical regions evaluated suggests that there was no evidence of genetic differentiation in their recent introduction in southern Brazil.

\section{ACKNOWLEDGMENTS}

This research was financially supported by The Conselho Nacional de Desenvolvimento Científico e Tecnológico (CNPq), Coordenação de Aperfeiçoamento de Pessoal de Nível Superior (CAPES), Fundação de Apoio a Pesquisa Científica e Tecnológica do Estado de Santa Catarina (FAPESC) and Universidade do Estado de Santa Catarina (UDESC).

\section{REFERENCES}

AMPONSAH, N.P. et al. Agar media for isolation of Neonectria ditissima from symptomatic and asymptomatic apple tissues and production of infective conidia. New Zealand Plant Protection, v.67, p.116-122, 2014. Available from: <https://www.nzpps.org/ journal/67/nzpp_671160.pdf $>$. Accessed: Oct. 2016.

BARNARD, E.L. et al. Comparative spore morphology and pathogenicity of four Florida isolates of Nectria galligena. Plant Disease, v.72, p.973-976, 1988. Available from: <https:// www.freshfromflorida.com/content/download/4629/29544/ Comparative\%20Spore\%20Morphology.pdf>. Accessed: Oct. 2016. doi: 10.1094/PD-72-0973.

BOGO, A. et al. Morphological characterization of Cryptosporiopsis perennans isolates in different culture media. Tropical Plant Pathology, v.3, p.248-251, 2008. Available from: <http://www.scielo. br/scielo.php?script=sci arttext\&pid=S1982-56762008000300013>. Accessed: Oct, 2016. doi: 10.1590/S1982-56762008000300013.

BOOTH, C. The genus Cylindrocarpon. Mycological Papers, v.104, p.1-56, 1966. Available from: <http://www.mycobank.org/ BioloMICS.aspx?TableKey $=14682616000000061 \&$ Rec $=2138 \&$ Fields $=$ All $>$. Accessed: Oct. 2016.

BRASIL, Ministério da Agricultura, Pecuária e Abastecimento (MAPA), Gabinete do Ministro. Instrução Normativa n. 20, Brasília, 2013. DOU de 14/10/2016, n. 198, Seção 1, p. 12. BRAYFORD, D. et al. Neonectria and Cylindrocarpon: the Nectria mammoidea group and species lacking microconidia. Mycologia, v.96, p.572-597, 2004. Available from: <http://www.mycologia. org/content/96/3/572.full.pdf+html $>$. Accessed: Oct. 2016.

CASTLEBURY, L.A. et al. Phylogenetic relationships of Neonectria/Cylindrocarpon on Fagus in North America. Canadian Journal of Botany, v.84, p.1417-1433, 2006. Available from: $<$ http://www.ascofrance.com/uploads/forum_file/Neonectria-onFagus-0001.pdf $>$. Accessed: Oct. 2016.

CHAVERRI, P. et al. Delimitation of Neonectria and Cylindrocarpon (Nectriaceae, Hypocreales, Ascomycota) and related genera with Cylindrocarpon-like anamorphs. Studies in Mycology, v.68, p.57-78, 2011. Available from: <http://www. ascofrance.com/uploads/forum_file/Neonectria-on-Fagus-0001. pdf>. Accessed: Oct. 2016. 
FLACK, N.J.; SWINBURNE, T.R. Host range of Nectria galligena Bres. and the pathogenicity of some Northern Ireland isolates. Transactions of the British Mycological Society, v.68, p.185-192, 1977. Available from: <http://www.sciencedirect.com/science/article/ pii/ S0007153677800077>. Accessed: Oct. 2016. doi: 10.1016/S00071536(77)80007-7.

HARDING, H. Effect of $\mathrm{pH}$ and sucrose concentration on conidium size and septation in four Bipolaris species. Canadian Journal of Botany, v.53, p.1457-1464, 1975. Available from: <http://www. nrcresearchpress.com/doi/abs/10.1139/b75-178\#.WAZ6a krKUk>. Accessed: Oct. 2016. doi: 10.1139/b75-178.

LANGRELL, S.R.H. Molecular detection of Neonectria galligena (syn. Nectria galligena). Mycological Research, v.106, p.280-292, 2002. Available from: <http://www.sciencedirect.com/science/article/ pii/S095375620860043X>. Accessed: Oct. 2016. doi: 10.1017/ S095375620200552X.

LEHNER, M.S. et al. Sclerotia morphology traits and mycelial growth rate are not informative variables for population studies of Sclerotinia sclerotiorum. Tropical Plant pathology, v.39, p.471-477, 2014. Available from: <http://www.scielo.br/scielo.php?script=sci arttext\&pid=S1982-56762014000600009>. Accessed: Oct. 2016. doi: $10.1590 /$ S1982-56762014000600009.

MAGUIRE, J.D. Speed of germination-aid in selection and evaluation for seedling emergence and vigor. Crop Science, v.2, p.76-177, 1962. Available from: <https://dl.sciencesocieties. org/publications/cs/abstracts/2/2/CS0020020176/>. Accessed: Oct. 2016.

NOZAKI, M.H. et al. Characterization of Diaporthe citri under different culture media, temperature and luminosity conditions. Fitopatologia Brasileira, v.29, p.429-432, 2004. Available from: <http://www.scielo.br/scielo.php?script=sci_arttext\&pid $=$ S0100-41582004000400012>. Accessed: Oct. 2016. doi:10.1590/ S0100-41582004000400012.

SANHUEZA, R.M.V. Cancro Europeu das Pomáceas (Nectria galligena). Bento Gonçalves: Embrapa Uva e Vinho, 1998. 16p. (Circular Técnica 23).

SAHA, A. et al. Influence of culture media and environmental factors on mycelial growth and sporulation of Lasiodiplodia theobromae (Pat.) Griffon and Maubl. Journal of Environmental Biology, v.29, p.407-410, 2008. Available from: <http://www.jeb.co.in/journal_issues/200805_may08/ paper_24.pdf $>$. Accessed: Oct. 2016.

WEBER, R.W.S. Biology and control of the apple canker fungus Neonectria ditissima (syn. N. galligena) from a Northwestern European perspective. Erwerbs-Obstbau, v.56, p.95-107, 2014. Available from: <http://link.springer.com/article/10.1007/ s10341-014-0210-x>. Accessed: Oct. 2016. doi: 10.1007/ s10341-014-0210-x. 